\title{
CORD BLOOD LIPIDS OF NORMAL INFANTS AND INFANTS OF DIABETIC MOTHERS
}

\author{
BY \\ J. G. MORTIMER* \\ From the University Department of Paediatrics and Child Health, and the Children's Hospital, Birmingham
}

(RECEIVED FOR PUBLICATION JANUARY 17, 1964)

Cord blood serum lipids are much lower than those of adults. Two recent studies of cord blood lipids of infants of diabetic mothers (Pantelakis, Cameron, Davidson, Dunn, Fosbrooke, Lloyd, Malins, and Wolff, 1964; Lloyd, 1963) suggest that certain lipid fractions are higher in these infants than in infants of normal mothers. In view of recent work suggesting that in diabetes mellitus a disturbance of lipid metabolism may precede that of carbohydrate metabolism (Randle, Garland, Hales and Newsholme, 1963), it was decided to reinvestigate cord blood lipids in infants of diabetic mothers and to compare them with those of normal infants.

\section{Material and Methods}

Cord blood was obtained from 20 normal infants and 13 infants of diabetic mothers delivered in the Birmingham Maternity Hospital.

The normal infants, who were delivered vaginally, were mature with birth weights ranging from $6 \mathrm{lb}$. $15 \mathrm{oz}$. $(3,146 \mathrm{~g}$.) to $9 \mathrm{lb} .13 \mathrm{oz}$. $(4,450 \mathrm{~g}$.) and remained healthy during the neonatal period. None of their mothers had diabetes (potential or actual) as defined by the British Diabetic Association (1964).

The infants of the diabetic mothers were delivered between the 35th and 38th weeks of gestation. 11 being delivered by caesarean section and 2 per vaginam: 10 of them showed a cushingoid appearance at birth, the other 3 appeared normal. The known duration of maternal diabetes varied from 15 months to 23 years and all the mothers received insulin during the pregnancy.

Blood samples were taken by syringe and needle from the umbilical vein at delivery. The clotted blood was stored at $4 \mathrm{C}$. until the serum could be separated, which was always within a period of 24 hours. The serum was then stored at $-20^{\circ} \mathrm{C}$. Lipid extracts of the serum were made according to the method of Bloor (1914). Total lipid was estimated by the method of de la Huerga, Yesinick and Popper (1953). Total cholesterol was

* Present address: The Institute of Child Health, Camperdown, N.S.W. Australia. estimated by the method of Sackett (1925) with the following modifications.

(1) Unconjugated bilirubin, which is present in lipid extracts and forms, like cholesterol, a green chromogen with the Lieberman-Burchard reagent (Babson, Shapiro and Phillips, 1962), was removed by adsorption from the extract with dry aluminium oxide (B.D.H. aluminium oxide for chromatographic analysis- $-0.1 \mathrm{~g}$. of powder to $4 \mathrm{ml}$. lipid extract).

(2) The time allowed for colour development after addition of the Lieberman-Burchard reagent was increased to 20 minutes, because at this time the colour is more stable.

Total phospholipid was estimated by an adaptation (J. G. L. Mortimer and D. N. Raine, personal communication) of the method of Gomori (1942).

The precision of the methods is shown in Table 1. The standard deviation (S.D.) of the methods was estimated by the technique described by Snedecor (1952) using the formula: $\mathrm{SD}=\sqrt{\frac{d^{2}}{2 N}}$ where $d$ is the difference between the two results in a duplicate determination and $N$ the number of duplicate determinations performed.

TABLE 1

PRECISION OF THE METHODS

\begin{tabular}{|c|c|c|c|c|}
\hline & & $\begin{array}{l}\text { Number of } \\
\text { Duplicate } \\
\text { Determina- } \\
\text { tions }\end{array}$ & $\begin{array}{c}\text { Range of } \\
\text { Values } \\
\text { (mg. } 100 \mathrm{ml} . \\
\text { serum) }\end{array}$ & $\begin{array}{r}\text { Standard } \\
\text { Deviation }\end{array}$ \\
\hline $\begin{array}{l}\text { Total lipids } \\
\text { Total cholesterol } \\
\text { Total phospholipid }\end{array}$ & $\begin{array}{l}\cdots \\
\cdots \\
\cdots\end{array}$ & $\begin{array}{l}38 \\
38 \\
34\end{array}$ & $\begin{array}{c}150-1035 \\
38-280 \\
59-284\end{array}$ & $\begin{array}{c}11 \\
3 \\
5 \cdot 5\end{array}$ \\
\hline
\end{tabular}

\section{Results}

The results of the cord serum lipid estimations are shown in Table 2. The higher mean lipid values for the infants of diabetic mothers and the wide standard deviations are due in part to one infant in this group with extraordinarily high levels (total lipid $1,035 \mathrm{mg}$. 
/100 ml., total cholesterol $272 \mathrm{mg} . / 100 \mathrm{ml}$., and total phospholipid $278 \mathrm{mg}$. $100 \mathrm{ml}$.). Most of the cord haemoglobin of this infant was foetal haemoglobin and a materno-foetal transfusion could, therefore, not have caused the high lipid levels.

When this infant is excluded from the series, the mean cord serum lipid levels of the infants of diabetic mothers are: total lipid $295 \mathrm{mg} . / 100 \mathrm{ml}$., total cholesterol $91 \mathrm{mg}$. $100 \mathrm{ml}$., and total phospholipid $117 \mathrm{mg} . / 100 \mathrm{ml}$. Only the mean cholesterol level remained appreciably higher than in the normal group, but this difference was not statistically significant.

\section{Discussion}

Determination of low levels of lipid such as occur in cord serum presents technical problems particularly for cholesterol. Normal cord sera may contain as much as $2 \mathrm{mg}$. $100 \mathrm{ml}$. of unconjugated bilirubin. With the Lieberman-Burchard reagent bilirubin forms a green chromogen which has an absorption five to nine times as great as an equivalent concentration of cholesterol (Babson et al., 1962). From experiments with the addition of bilirubin to serum lipid extracts, I was able to conclude that $1 \mathrm{mg} . / 100$ $\mathrm{ml}$. of unconjugated bilirubin gives a positive error of about $4 \mathrm{mg}$./ $100 \mathrm{ml}$. in the cholesterol determination; thus in a cord serum containing $70 \mathrm{mg} . / 100 \mathrm{ml}$. of cholesterol and $2 \mathrm{mg}$. $/ 100 \mathrm{ml}$. of bilirubin a positive error of about $10 \%$ in the cholesterol value is introduced, unless the bilirubin is removed from the lipid extract. The method used in this study for removing bilirubin was satisfactory.

The mean lipid values found in the normal infants are in fair agreement with those of the most recently reported studies (Table 3). Pantelakis et al. (1964) found significantly higher mean levels of total cholesterol and total phospholipid in the infants of diabetic mothers than in normal infants. Lloyd (1963) also found higher cholesterol levels but no difference between the phospholipid levels. The results of these studies are summarized in Table 4. Although in the present study the difference between the lipid levels of the infants of diabetic and nondiabetic mothers has not reached statistical significance calculation of the weighted mean difference of cholesterol levels in the three series shows it to be

TABLE 2

CORD BLOOD LIPIDS

\begin{tabular}{|c|c|c|c|}
\hline \multirow[b]{3}{*}{$\begin{array}{l}\text { Normal infants (20) } \ldots \\
\text { Infants of diabetic mothers }(13 \text {, }\end{array}$} & \multicolumn{3}{|c|}{ Lipids (mg $100 \mathrm{ml}$, mean and S.D.) } \\
\hline & Total Lipid & Total Cholesterol & Total Phospholipid \\
\hline & $\left.\begin{array}{l}293(102) \\
352(224)\end{array}\right) \begin{array}{l}t=0.89 \\
\mathrm{p}=0.4\end{array}$ & $\left.\begin{array}{c}75(25) \\
105(63)\end{array}\right\} \begin{array}{l}t=1 \cdot 68 \\
\mathrm{p}=0 \cdot 1\end{array}$ & $\left.\begin{array}{c}113(31) \\
129(55)\end{array}\right\} \begin{array}{r}t=0.96 \\
\mathrm{p}=0.4 \\
-0.3\end{array}$ \\
\hline
\end{tabular}

TABLE 3

CORD BLOOD LIPIDS IN NORMAL INFANTS

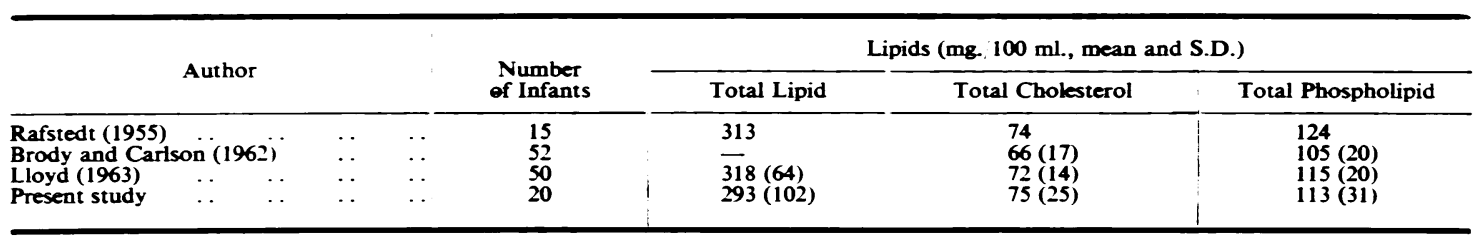

TABLE 4

CORD BLOOD LIPIDS IN NORMAL INFANTS AND INFANTS OF DIABETIC MOTHERS

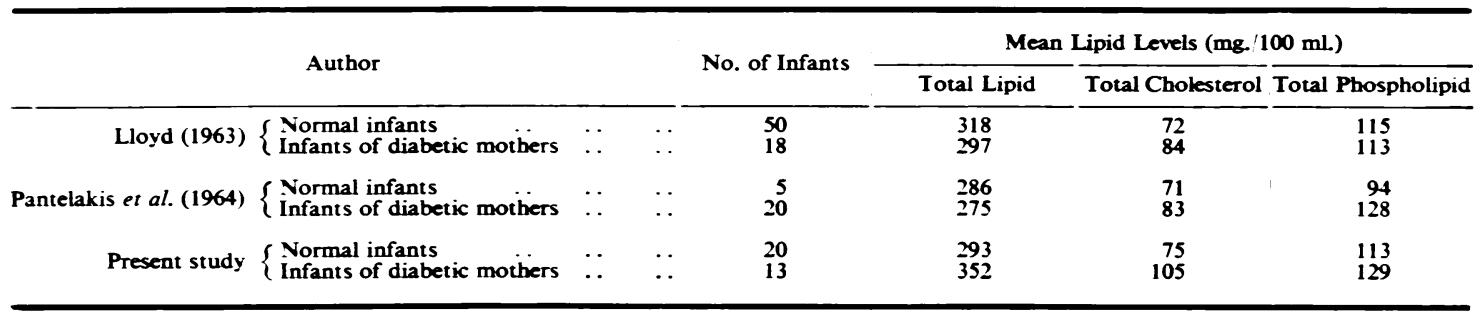


highly significant $(p<0.001)$. Neither in normal infants nor in infants of diabetic mothers is there a correlation between the cord blood cholesterol on the one hand and maturity or birth weight of the infant, or mode of delivery on the other (Rafstedt, 1955; Pantelakis et al., 1964). Pantelakis et al. suggested that the relatively high levels of cholesterol and phospholipid in the cord blood of the infants of diabetic mothers might result from the passage of non-esterified fatty acids across the placenta and subsequent synthesis of large lipoprotein molecules.

\section{Summary}

Total lipids, cholesterol, and phospholipid have been estimated in the cord serum of 20 normal infants and 13 infants of diabetic mothers. The mean levels for the normal infants were total lipid $293 \mathrm{mg}$. $100 \mathrm{ml}$., total cholesterol $75 \mathrm{mg}$. $/ 100 \mathrm{ml}$., and total phospholipid $113 \mathrm{mg}$. $/ 100 \mathrm{ml}$., and for the infants of diabetic mothers, total lipid $352 \mathrm{mg}$. $/ 100 \mathrm{ml}$., total cholesterol $105 \mathrm{mg}$./100 ml., and total phospholipid $129 \mathrm{mg} . / 100 \mathrm{ml}$. Pantelakis et al. (1964) and Lloyd (1963) also found a higher mean cholesterol level in infants of diabetic mothers, and the weighted mean difference of cholesterol levels in the three series is highly significant.

I am grateful to Dr. J. K. Lloyd and Dr. O. H. Wolff for suggesting this study and for their continued interest in it, and also to Miss A. S. Fosbrooke and Dr. D. N.
Raine for their help and advice with the biochemical methods.

I wish to thank the consultant staff of the Birmingham Maternity Hospital and in particular Mr. S. Davidson, Dr. J. M. Malins, and Dr. B. S. B. Wood for the opportunity to study their patients.

\section{REFERENCES}

Babson, A. L., Shapiro, P. O. and Phillips, G. E. (1962). A new assay for cholesterol and cholesterol esters in serum which is not affected by bilirubin. Clin. chim. Acta, 7, 800 .

Bloor, W. R. (1914). A method for the determination of fat in small amounts of blood. J. biol. Chem., 17, 377.

British Diabetic Association (1964). A suggested classification of early diabetes. Lancet. In the press.

Brody, S. and Carison, L. A. (1962). Plasma lipid concentrations in the newborn with special reference to the distribution of the different lipid fractions. Clin. chim. Acta, 7, 694.

de la Huerga, J., Yesinick, C. and Popper, H. (1953). Estimation of total serum lipids by a turbidimetric method. Amer. J. clin. Path., 23, 1163.

Gomori, G. (1942). A modification of the colorimetric phosphorus determination for use with the photoelectric colorimeter. J. Lab. clin. Med., 27, 955.

Lloyd, A. V. (1963). Ph.D. Thesis, University of Edinburgh.

Pantelakis, S. N., Cameron, A. H., Davidson, S., Dunn, P. M., Fosbrooke, A. S., Lloyd, J. K., Malins, J. M., and Wolf, O. H. (1964). The diabetic pregnancy. A study of serum lipids in maternal and umbilical cord blood and of the uterine and placental vasculature. Arch. Dis. Childh., 39, 334.

Rafstedt, S. (1955). Studies on Serum Lipids and Lipoproteins in Infancy and Childhood. Acta paediat. (Uppsala), Suppl. 102

Randle, P. J., Garland, P. B., Hales, C. N. and Newsholme, E. A. (1963). The glucose fatty-acid cycle; its role in insulin sensitivity and the metabolic disturbances of diabetes mellitus. Lancet, 1, 785.

Sackett, G. E. (1925). Modification of Bloor's method for the determination of cholesterol in whole blood or blood serum. J. biol. Chem., 64, 203.

Snedecor, G. W. (1952). Biometrics, 8, 85. 